\title{
The effectiveness of advance organizers versus textual enhancement on learning inchoatives and unaccusatives
}

\author{
A'lipour, Javad $\bowtie$ \\ University of Isfahan, Iran (alipour.edu@gmail.com) \\ Youhanaee, Manijeh \\ University of Isfahan, Iran (youhanaee_m@hotmail.com) \\ Barati, Hossein \\ University of Isfahan, Iran (h.barati@gmail.com)
}

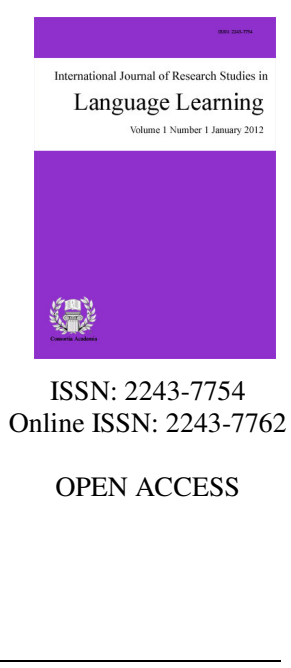

\section{Abstract}

This study was an attempt to investigate the effectiveness of advance organizers and textual Enhancement (TE) on the acquisition of inchoative and unaccusative verbs by EFL learners. A hundred EFL Persian-speaking learners in four intact classes constituted the groups. One of the experimental groups was exposed to Intralingual advance organizers (Intra-AOs). The second group received Interlingual advance organizers (Inter-AOs), and the third one was presented with textually enhanced material. The results of the study indicated that with unaccusative verbs, the TE and Intra-AO groups outperformed the Inter-AO group, with a statistically significant difference. With inchoative verbs, on the other hand, all the experimental groups performed similarly well with no significant difference between and among them. The implications of the results for theory and practice are discussed.

Keywords: inchoative verbs; interlingual advance organizers (Inter-AOs); intralingual advance organizers (Intra-AOs); passivization; textual enhancement (TE); unaccusative verbs 


\section{The effectiveness of advance organizers versus textual enhancement on learning inchoatives and unaccusatives}

\section{Introduction}

The second language acquisition (SLA) literature is replete with studies that underscore the importance of grammar teaching. Nassaji and Fotos (2004) identify a number of reasons why grammar instruction has taken a prominent role in today's debates. The first reason they adduce forward to support their argument concerns the noticing hypothesis (Schmidt, 1990, 2001) which is based on the premise that the acquisition of every aspect of a second language requires conscious attention on the part of learners (Doughty, 2001; Bygate, Skehan, \& Swain, 2001; Bialystok, 1994; Dekeyser, 1998; R. Ellis, 2002; Fotos, 1993, 1994). It must be pointed out, however, that not every second language researcher subscribes to this hypothesis, and some have argued that noticing does not translate into acquisition (Truscott, 1998).

Another reason they put forth for the resurgence of the role of grammar has to do with the teachability hypothesis (Pienemann, 1984, 1988, 1999). The teachability hypothesis suggests that while certain developmental sequences evade instruction, other structures would well lend themselves to being incorporated into the second language teaching material. One caveat that this theory admits to, however, is that the structures amenable to instruction ought to be matched with the learners' developmental stage (Lightbown, 2000). A third reason for the positive new outlook towards grammar is the fact that the results of exclusively meaning-centered approaches to teaching language have turned out to be a far cry from the expectations (Harley \& Swain, 1984; Lapkin, Hart, \& Swain, 1991; Swain, 1985). In addition, a number of studies have led to the conclusion that instruction of target grammar items does lead to considerable gains (Ellis, 1985, 1990, 1994, 2002a; Larsen-Freeman \& Long, 1991; Long, 1983, 1988, 1991).

Given the fact that grammar instruction has come to assume a sound footing in SLA instruction, EFL researchers and practitioners are on the lookout for ways in which this important component of language could be more effectively taught and acquired. In the current study, two of these methods that look potentially effective were compared; textual enhancement and advance organizers. A brief review of the research findings on these two methods is provided below.

\subsection{Textual Enhancement}

Considered as an external form of input enhancement, textual enhancement is a technique which is intended to draw learners' attention to linguistic forms in the input. The reason it is referred to as an external form of input enhancement concerns the fact that the learner's internal cognitive processes are not necessarily engaged when certain aspects of the text are enhanced. This point has been captured by various scholars in terms of the difference between consciousness-raising and textual enhancement (VanPatten, 1996). The technique is also considered as an implicit form of input enhancement because it occurs in situations where the learners' focus is on meaning, and is incidentally drawn to form. It is contrasted with such other techniques as processing instruction which is considered as an explicit form of input enhancement by virtue of the fact that in the latter the learners are provided with opportunities for consistent form-meaning mappings. Another requirement of a focus on form approach that textual enhancement seems to well meet is that it is provided in meaningful texts, thereby ensuring that meaning-form mapping occurs (Doughty \& Williams, 1998).

Whether TE is effective enough to lead to noticing and learning of the target structures of a second language has been the subject of a number of second language studies, and the results have turned out to be mixed. Jourdenais et al. (1995) investigated into the effects that TE could engender in terms of noticing and processing of target items, and it was concluded that the learners exposed to textually enhanced material outperformed those 
in the control group on measures of noticing and production of the forms in question. Doughty (1991) suggested that TE did seem to increase noticing on the part of the learners, but the findings were inconclusive as the learners in their study were exposed to such other techniques as rephrasing and rule presentation in addition to TE. Alanen (1995) carried out a study comparing the effects of explicit instruction as opposed to TE on the acquisition of French locative features and consonant gradation. The results indicated that TE did produce considerably better results. White (1998) investigated the idea of whether TE can lead to noticing and acquisition of third person singular possessives in English, and found that the effects of TE can be observed as far as noticing is concerned, but fail to translate into development of the target items. Izumi (2002) also found no significant difference between the enhanced and unenhanced group in terms of comprehension of relative clauses except for the fact that the learners in the enhanced group were shown to have increased noticing of the target structures.

\subsection{Advance Organizers}

Ausubel (1960) was the first scholar who coined the term advance organizer to refer to the idea that learners need to move from the known to the unknown. The definition that he put forth for the term gave a clear indication that he was seeking ways to operationalize his theory of subsumption, maintaining that learning happens through a process in which the to-be-learnt material is linked to previously-known information. The theory was based on the premise that human beings do not embark on the path of learning from scratch, that they do have chains of knowledge in place to fall back on. He defined advance organizers as "appropriately relevant and inclusive introductory materials that are maximally clear and stable. . . introduced in advance of the learning material itself, used to facilitate establishing a meaningful learning set" (p. 268). The subsumption theory along with the tools aimed at proving it, i.e. advance organizers, has its origin in educational psychology, but it has also been put to test by second language researchers (e.g., Chung \& Huang, 1998; Hanley et al., 1995; Herron et al., 1998; Kirkman \& Shaw, 1997; Alvermann, 1981; Denner \& Rickards, 1987; Glover, 1989; King, 1992; Osman \& Hannafin, 1994).

The effects of advance organizers have also been investigated by a number of studies in second language learning research. The advance organizers in these studies have mostly been in the form of videos and pictures and have for the most part set listening comprehension as their target. Herron (1994) explored the effects of video advance organizers used in combination with description, and found that the AO group outperformed on comprehension and retention tests. He used pictures as advance organizers and compared the effects of the combination of pictures and description with description alone. Herron et al. (1998) exposed beginner foreign language learners to either of two conditions; description+ pictures and description only conditions. The results indicated that the AO group outperformed the description only group. Hanely et al. (1995) compared the effects of two types of advance organizers; videos versus pictures plus teacher narrative. The results indicated that the video AOs outperformed the pictures plus teacher narrative condition. Ginther (2002) also investigated the effects of visual advance organizers on learners' listening comprehension. The findings suggested that visuals could lead to substantial gains on task performance. Finally, Vandergrift (2004) maintained that content-related AOs could engender more effective impacts than context-related AOs.

A review of the research literature on AOs makes clear the point that most of these studies have been concerned with the effects of AOs on the listening comprehension of EFL learners, and that there appears to be a research lacuna concerned with the idea of whether the same effects would have accrued if the target structure had been the grammatical system of a second language. This is what sets the current study apart from the various other studies that have investigated into the effects of advance organizers. As pointed out at the outset of the article, grammar instruction is widely recognized as a principle in SLA research and pedagogy, and it remains to be seen whether AOs can be seen to be productive tools in this direction. We used two types of advance organizers; intralingual or interlingual AOs. Intralingual advance organizers were characterized in the current study as those that use relevant items from the second language as background knowledge to be activated, and interlingual advance organizers were defined as those which are intended to induce the learners' attention to a 
A'lipour, J., Youhanaee, M., \& Barati, H.

form existing in the learners' mother tongue. To put to empirical investigation the relative effects of AOs as compared to textual enhancement on the acquisition of the grammatical properties of inchoative and unaccusative verbs by EFL learners, the following research questions were posed:

1. Do Inter-AOs lead to the acquisition of inchoatives and unaccusatives?

2. Do Intra-AOs lead to the acquisition of inchoatives and unaccusatives?

3. Does the use of TE lead to the acquisition of inchoatives and unaccusatives?

4. How are the effects of Inter-AOs and Intra-AOs compared with those of TE in the acquisition of inchoatives and unaccusatives?

\section{Materials and Method}

\subsection{Participants}

A hundred intermediate learners aged 15 to 22 who had enrolled in 3 language school courses were chosen to participate in the study. It must be pointed that all the language schools were found to use the same placement test along with an oral interview to assign learners to classes. However, to receive an assurance that the learners were also homogenous in terms of their mastery over the particular target structure of interest in the current study, a pretest was constructed by the researchers and administered prior to the beginning of the study. The pretest covered a number of grammatical structures in addition to the inchoative and unaccusative verbs. The incorporation of items testing structures other than that of our interest was done with the aim of preventing the participants from guessing the focus of the research.

As can be seen in Table 1, all the groups involved in the study displayed similar little knowledge of the target structures. In terms of the participants' knowledge of unaccusative verbs, the groups do not differ by any large margins with the total average mean being 1.42. Likewise, with respect to the learners' knowledge of inchoative verbs, the groups are very much similar with the total average mean being 1.42 . The groups are also alike in terms of within-group variability, adding to the homogeneity of the groups in terms of the mastery of the target structures.

\section{Table 1}

Results of Learners' Performance on Inchoatives and Unaccusatives

\begin{tabular}{llllll}
\hline & & $n$ & Mean & Std. Deviation & Std. Error \\
\hline Pretest Results on & Intra-AO Group & 25 & 1.32 & .47610 & .09522 \\
Unaccusatives & Inter-Ao Group & 25 & 1.40 & .50000 & .10000 \\
& TE Group & 25 & 1.48 & .50990 & .10198 \\
& Control Group & 25 & 1.48 & .65320 & .13064 \\
& Total & 100 & 1.42 & .53522 & .05352 \\
\hline Pretest Results on & Intra-AO Group & 25 & 1.32 & .47610 & .09522 \\
Inchoatives & Inter-Ao Group & 25 & 1.44 & .50662 & .10132 \\
& TE Group & 25 & 1.48 & .50990 & .10198 \\
& Control Group & 25 & 1.44 & .50662 & .10132 \\
& Total & 100 & 1.42 & .49604 & .04960 \\
\hline
\end{tabular}

\subsection{Materials}

The target structure chosen to be exposed to the learners was inchoatives and unaccusatives. The reason for 
the selection of these forms was that intermediate learners seem to have particular difficulty acquiring them, resulting in overpassivization errors. Yip (1995) observes that advanced Chinese speakers of English have been shown to have difficulty with unaccusative verbs, resulting in errors with the passivized forms of these verbs.

An unaccusative verb is a kind of intransitive verbs. What distinguishes it semantically is the fact that the subject of such verbs does not actively initiate the action of the verb, nor is it taken to be actively responsible for the action expressed by the verb. For example, the verb die is considered an unaccusative verb on account of the fact that the subject neither initiated the action, nor is responsible for it. Therefore, the subject a verb like die seems to have properties that it can share with the direct object of a transitive verb like kill. Other examples of unaccusatives include Arrive, die, and fall. Take note of the fact that there is an obvious semantic distinction between these verbs and such other verb as run, resign, etc. In the latter type of verbs, the action expressed by the verb is initiated by the subject, whereas in the former ones, there is no intervention on the part of the subject of the sentence. An important point worth mentioning here is that passivization of unaccusative verbs results in ungrammaticality. Hence, it would be ungrammatical to say *It is died or *I am coughed (Perlmutter \& David, 1978). The assumption on the part of English-as-a-second-language learners that these kinds of verbs can be passivized in the manner accusative verbs are is referred to as overpassivization which is an area targeted by the current study.

Inchoatives, on the other hand, are those which can be used in either of two alternate forms, i.e., transitive and intransitive, with the transitive alternate being sometimes referred to as the ergative form of the verb. For example, in the sentence The plate broke the verb broke is an inchoative verb. Most inchoative verbs are considered to be change-of-state verbs (Balcom, 1997) such as increase, break, open, boil, freeze. Balcom makes the point that ESL learners seem to view not only inchoatives but all unaccusatives as alternating. He concludes that we ought to be seeking ways to teach learners effectively that only change-of-state verbs like increase have a transitive and intransitive form.

The pretest results as shown in Table 1 clearly indicate that the learners in the study had little knowledge of the target structures in question. The pretest results also indicated that the learners did have knowledge of 6 English tenses; therefore, the two types of verbs in question, i.e. inchoative and unaccusative verbs, were presented to them in all the six tenses. The presentation of each of the two types of verbs were done in the form of 4 Powerpoint presentations manipulated with respect to the experimental conditions that the study set out to investigate. The 4 Powerpoint presentations created for each tense were alike except for the difference in the way the target structures were conveyed.

The Powerpoint presentations for the Inter-AO group each consisted of 2 slides. In the first slide, there were 4 Persian passive sentences with verbs equivalent to the inchoative and unaccusative English counterparts, and in the second there was a reading passage in English with inchoatives and unaccusatives embedded in it. The purpose of the first slide was to implicitly prime the learners to the target forms through the use of an interlingual advance organizer, and the purpose of the second slide was to present the actual target structures intended to be acquired by the learners. The Powerpoint presentations for the Intra-AO group also consisted of two slides. The first slide displayed 4 English active sentences with the verbs in question each followed with their passive counterpart. It should be pointed out that the active sentences in the first slide were used as operationalizations of the Intra-AOs. The second slide did not differ from the second slide exposed to the Inter-AO group. The Powerpoint presentation created for the TE group had, likewise, two slides in the first one of which the verbs in question were italicized. In the second slide, the same reading passage the other two groups received was displayed, with the difference that the target forms in the text had been textually enhanced through highlighting. The Powerpoint presentations were then submitted to 3 expert judges with PhDs in Applied Linguistics. In line with the comments of the judges, a number of minute modifications were made to the slides.

As for the testing instruments, 2 pretests and 2 posttests were used each of which consisted of 30 items twenty of which targeted the knowledge of the participants of the two verb forms in question. The remaining 10 
items were included to prevent the possibility that the target structures of the study would be given away. An equivalent test was also designed to be used as the posttest.

\subsection{Procedure}

At the outset of the study, the participants were asked to give their consent as to the allocation of time to the research. The officials along with the teachers gave their written consent to the allocation of the first 15 minutes of each session to the treatment. The learners went about following their everyday schedule attending their regular classes 2 times a week. The treatment phase of the study lasted over 24 sessions spread out over 12 weeks. One of the researchers of the study was assigned the task of displaying the Powerpoint presentations to the learners and asking the participants to read the text appearing on each slide.

The beginning 15 minutes of five in-a-row sessions were dedicated to each of the two verb forms. As we were interested in investigating the degree to which the different types of exposure in question were potentially productive, we did not make any interventions, and merely displayed the Powerpoint presentations. It must be pointed out that the reading passages in the Powerpoint presentations were the same for all the groups involved. As for the input exposed to the experimental groups, it was intended to inculcate into the learners' minds that unaccusative verbs cannot be passivized, and that inchoative verbs can be used in two alternate forms. A summary of the different types of exposure each group was presented with has been provided below.

Inter-AO group: For each of the two types of verb forms, 4 Powerpoint presentations containing Persian sentences with the Persian verbs equivalent to English inchoatives and unaccusatives followed with corresponding English sentences plus a reading passage containing the target structures.

$>$ Intra-AO group: For each of the two verb forms, five Powerpoint presentations containing five English sentences with transitive verbs followed with sentences using inchoative and unaccusative verbs and a reading passage containing sentences using the two types of verbs in question. It must be pointed out that the two types of verbs were repeated the same number of times. It must also be noted that the transitive verbs presented to the learners prior to the unaccusative verbs were chosen based on the semantic similarity of these verbs with those which happened to have a transitive counterpart. For example, prior to the presentation of the verb die as an unaccusative verb, the verb kill, an a transitive counterpart, was presented to the learners with sample sentences in which it had been used.

$>$ TE group: For each of the two verb forms, 5 two-slide Powerpoint presentations, with the first one containing italicized target forms and the second one containing a reading passage with the target structures highlighted throughout.

$>$ Control group: For each of the two verb forms, 5 Powerpoint presentations containing reading texts with the target structures unenhanced.

\section{Results}

The first part of the results section of the paper deals with the analysis of the results of the study with respect to the impacts of the three grammar presentation methods on the acquisition of the grammatical properties of unaccusative verbs, and the second part is devoted to the influence that these three methods engender on the learning of inchoative verbs. In grading the pretest and the posttest, each correct response received a mark of one, and each wrong answer was assigned a mark of zero by the researchers. As the test each consisted of 20 items, a student who had got all the answers right would end up getting a score of 20.

As can be seen in Table 2, the learners' descriptive performance on the unaccusative verbs, as gauged on the pretest, has been shown and compared with their performance on the posttest. A quick look through the table suggests that the learners in all the experimental groups have made considerable progress in their mastery of the target structures. While the means of the groups are shown to have differed only slightly at the outset of the study, 
The effectiveness of advance organizers versus textual enhancement on learning inchoatives and unaccusatives their performances on the posttest differ substantially from each other, with the TE group and the Intra-AO group taking the lead, distancing them from the Inter-AO group by quite a large margin. As can be seen in the Table, the highest mean (18.44) belongs to the TE group, followed closely with the Intra-AO group (18.2). The Inter-AO group, though displaying rather remarkable gains compared with their initial performance, has ended up obtaining a mean of 15.32 .

Table 2

Comparison of Descriptive Statistics on Pretest and Posttest Results for Unaccusatives

\begin{tabular}{llllll}
\hline & & $n$ & Mean & Std. Deviation & Std. Error \\
\hline \multirow{3}{*}{ Pretest Results on } & Intra-AO Group & 25 & 1.32 & .47610 & .09522 \\
Unaccusatives & Inter-Ao Group & 25 & 1.40 & .50000 & .10000 \\
& TE Group & 25 & 1.48 & .50990 & .10198 \\
& Control Group & 25 & 1.48 & .65320 & .13064 \\
& Total & 100 & 1.42 & .53522 & .05352 \\
\hline \multirow{3}{*}{ Posttest Results on } & Intra-AO Group & 25 & 18.20 & .91287 & .18257 \\
Unaccusatives & Inter-Ao Group & 25 & 15.32 & .55678 & .11136 \\
& TE Group & 25 & 18.44 & .86987 & .17397 \\
& Control Group & 25 & 2.72 & .93630 & .18726 \\
& Total & 100 & 13.67 & 6.52432 & .65243 \\
\hline
\end{tabular}

Whether the differences between and among the groups have reached a significant difference according to which one can make plausible conclusions as to the effectiveness of the different treatments employed had to be decided through the use of an ANOVA. As can be seen in the following table, the ANOVA on the pretest results indicates the there has been no significant difference between the groups as they embarked on the study $(F=$ 0.504, $p<0.05)$. After the treatments, however, the ANOVA result points to the existence of some difference between the groups $(F=1.9, p<0.05)$.

Table 3

Results of ANOVA on Pretest and Posttest for Unaccusatives

\begin{tabular}{|c|c|c|c|c|c|c|}
\hline & & $\begin{array}{l}\text { Sum of } \\
\text { Squares }\end{array}$ & $d f$ & $\begin{array}{l}\text { Mean } \\
\text { Square }\end{array}$ & $F$ & Sig. \\
\hline \multirow[t]{3}{*}{ Pretest Results on Unaccusatives } & Between Groups & .440 & 3 & .147 & .504 & .680 \\
\hline & Within Groups & 27.920 & 96 & .291 & & \\
\hline & Total & 28.360 & 99 & & & \\
\hline \multirow[t]{3}{*}{ Posttest Results on Unaccusatives } & Between Groups & 4147.470 & 3 & 1382.490 & 1.99 & .000 \\
\hline & Within Groups & 66.640 & 96 & .694 & & \\
\hline & Total & 4214.110 & 99 & & & \\
\hline
\end{tabular}

Thus far, the results have led us to the idea that the groups are different in terms of their performance on the posttest. Exactly where and between which groups this difference may lie is still not clear, though a comparison of the means may be revealing to some extent. To get assured of the idea of where this difference could be detected, a Scheffe post hoc was conducted, and the multiple comparisons, as depicted in Table 4, clearly show that the results of the TE and the Intra-AO groups do not differ significantly, while both of the groups have outperformed the Inter-AO group, and the difference is significant. Furthermore, the Inter-AO group has significantly outperformed the control group with a mean difference of 12.60 . 
A'lipour, J., Youhanaee, M., \& Barati, H.

\section{Table 4}

Results of Scheffe Post-hoc on Posttest Results for Unaccusative Verbs

\begin{tabular}{llllll}
\hline Dependent Variable & Type of Presentation & Type of Presentation & Mean Difference & Std. Error & Sig. \\
\hline Posttest Results on & Intra-AO Group & Inter-Ao Group & $2.88^{*}$ & .23566 & .000 \\
Unaccusatives & & TE Group & -.24 & .23566 & .792 \\
& & Control Group & $15.48^{*}$ & .23566 & .000 \\
\hline \multirow{4}{*}{ Inter-Ao Group } & TE Group & $-3.12^{*}$ & .23566 & .000 \\
& & Control Group & $12.60^{*}$ & .23566 & .000 \\
& TE Group & Control Group & $15.72^{*}$ & .23566 & .000 \\
\hline
\end{tabular}

Overall, the performances of the groups on the posttest concerned with the unaccusative verbs indicated that whereas the students possessed relatively similar knowledge of the target structure, the treatments delivered to them have affected different impacts, with the TE group gaining the most, followed closely with the Intra-AO group. The TE group and the Intra-AO group were shown to have outperformed the Inter-AO group and the control group by a wide margin which turned out to be a statistically significant one according to the post-hoc results. It must also be noted that the Inter-AO group, though ranked last in the experimental groups, did outperform the control group, and the mean difference turned out to be a statistically significant one.

The second research question posed in the study was concerned with the effects of the three types of grammar presentation methods on the acquisition of inchoatives. As with the grading procedure of the pretest and posttest for unaccusatives, each correct response on the part of the learners received a mark of one, whereas each unanswered or wrongly-answered item was assigned a zero. Table 5 displays the descriptive statistics of the groups on the pretest and posttest for inchoative verbs. The results suggest that the groups have been at almost the same level of mastery of the target structures at the initial stage of the study, while they are not so after the treatment.

Table 5

Comparison of Descriptive Statistics on Pretest and Posttest Results for Inchoatives

\begin{tabular}{llllll}
\hline & & $n$ & Mean & Std. Deviation & Std. Error \\
\hline Pretest Results on & Intra-AO Group & 25 & 1.32 & .47610 & .09522 \\
Inchoatives & Inter-Ao Group & 25 & 1.44 & .50662 & .10132 \\
& TE Group & 25 & 1.48 & .50990 & .10198 \\
& Control Group & 25 & 1.44 & .50662 & .10132 \\
& Total & 100 & 1.42 & .49604 & .04960 \\
\hline Posttest Results on & Intra-AO Group & 25 & 18.40 & .76376 & .15275 \\
Inchoatives & Inter-Ao Group & 25 & 18.64 & 1.07548 & .21510 \\
& TE Group & 25 & 18.52 & .65320 & .13064 \\
& Control Group & 25 & 2.48 & .96264 & .19253 \\
& Total & 100 & 14.51 & 7.03454 & .70345 \\
\hline
\end{tabular}

The results of the posttest indicate that the three experimental groups have performed similarly well on the posttest with very close means. The highest mean belongs to the Inter-AO group (18.64), followed closely with the TE group (18.52), which is, in turn, followed closely with the Intra-AO group. Although the means are pretty close, to obtain more certainty about the fact that this minute difference between and among the groups does not reach a level of statistical significance, an ANOVA was run the results of which have been shown in Table 6. A quick look through the table reveals that the groups are quite alike in terms of their mastery of the target structure before the treatment phase begins $(F=0.48, p<0.05)$; however, there is a significant difference between the groups at the post-treatment phase $(F=2.08, p<0.05)$. 
The effectiveness of advance organizers versus textual enhancement on learning inchoatives and unaccusatives

An interesting point worth mentioning has to do with the comparative performance of the control group on the pretest and posttest, and the considerable gains that it made over the course of the study. As has been indicated, the control group has gained a mean of 1.42 on the pretest, and a mean of 2.48 on the posttest. It should, of course, be mentioned that the difference in the standard deviations of each of the tests moderates the difference to some extent.

Table 6

Results of ANOVA on Pretest and Posttest for Inchoatives

\begin{tabular}{|c|c|c|c|c|c|c|}
\hline & & Sum of Squares & $d f$ & Mean Square & $F$ & Sig. \\
\hline \multirow{3}{*}{$\begin{array}{l}\text { Pretest Results on } \\
\text { Inchoatives }\end{array}$} & Between Groups & .360 & 3 & .120 & .48 & .697 \\
\hline & Within Groups & 24.000 & 96 & .250 & & \\
\hline & Total & 24.360 & 99 & & & \\
\hline \multirow{3}{*}{$\begin{array}{l}\text { Posttest Results on } \\
\text { Inchoatives }\end{array}$} & Between Groups & 4824.750 & 3 & 1608.250 & 2.08 & .000 \\
\hline & Within Groups & 74.240 & 96 & .773 & & \\
\hline & Total & 4898.990 & 99 & & & \\
\hline
\end{tabular}

\section{Table 7}

Results of Scheffe Post-hoc on Posttest Results for Inchoatives

\begin{tabular}{llllll}
\hline $\begin{array}{l}\text { Dependent } \\
\text { Variable }\end{array}$ & Type of & Type of & \multicolumn{3}{c}{ Std. } \\
Presentation & Presentation & Mean Difference & Error & Sig. \\
\hline Posttest Results on & Intra-AO Group & Inter-Ao Group & -.24 & .24873 & .818 \\
& & TE Group & -.12 & .24873 & .972 \\
& & Control Group & $15.92^{*}$ & .24873 & .000 \\
\hline & Inter-Ao Group & TE Group & .12 & .24873 & .972 \\
& & Control Group & $16.16^{*}$ & .24873 & .000 \\
\hline
\end{tabular}

To shed light on the idea of where a statistically significant difference existed between and among the groups, a Scheffe post hoc was used. The results of the post hoc as displayed in Table 7 are indicative of the point that the difference between the experimental groups of the study fails to reach a level of significance. The experimental groups, on the other hand, have outperformed the control group, and have all done so with a significant level of difference.

\section{Discussion and Conclusions}

The first research question posed in the study was concerned with the effects of three types of grammar presentation, namely, Inter-AO, Intra-AO and TE groups on the acquisition of inchoatives and unaccusatives. As for the first question, a comparison of the results of the groups on the pretest and the posttest for the unaccusative verbs indicated that the TE group achieved the highest gains, but the Intra-AO group did not fall behind by any wide margins. The TE and Intra-AO groups outperformed the Inter-AO and control groups, and the difference between them turned out to be a statistically significant one.

A possible explanation for the supremacy of the results gained by the TE and Intra-AO group could be concerned with the idiosyncratic characteristics of unaccusative verbs. In other words, it is likely that the underlying cause of making errors with unaccusative verbs is the nature of the verbs in question, giving rise to the candidacy of TE and Inter-AOs as effective methods. The fact that in TE and Inter-AOs, the focus of the learners is drawn to the idiosyncratic features of the items in question, leading to more attention and in turn more effective acquisition by the learners, may corroborate this explanation. It could be argued that in the Inter-AO condition, on the other hand, the introduction of items of relevance from the learners' mother tongue may have produced little effect, as the links between the items from the learners' mother tongue and the particular verbs of 
interest in the study are not strong enough to bring about as robust a type of attention as do the Intra-AO and TE conditions. This could lead us to the interpretation that the underlying cause of errors with passivizaed unaccusative verbs may lie in the second language particularities, and an Intra-AO treatment with these verbs could, therefore, be more effective.

The results runs contrary to previous research results (Alipour, et al., 2014) indicating that Inter-AOs could be potentially more useful. This difference in the results could be interpreted in light of the fact Alipour et al. (2014) dealt with passivization, and it may be that as far as passivization is concerned, Inter-AOs could provide suitable grounds for the learners to draw the necessary analogies between the two language, and hence go from the known to the unknown. With unaccusatives, however, it seems that the suitable grounds of similarity are not provided. In other words, it may be the particular characteristics associated with unaccusatives which render them demanding on the learners' attentional system to the extent that focus on the particular target structure per se could be more effective.

Inchoative verbs, on the other hand, do not have the idiosyncrasy associated with unaccusatives as they can be used in either of two forms, i.e., both in the accusative case and the unaccusative case. These verbs may have presented themselves as being less demanding as the learners were left with two alternatives as to how to treat these verbs. This could be a possible justification for the similarly good performance of all the experimental groups on the posttest for inchoative verbs. Given the fact that a lot of English-as-a-second-language practitioners in the field have attested to the problems encountered when presenting learners with unaccusatives, Intra-AOs and TE could be suggested as ways to remedy these problems to some extent. On the other hand, it seems that students and teachers are better off when dealing with inchoative verbs, and any of the treatments delivered in the study could be potentially useful.

The results of the study also suggest that AOs, be they of an interlingual or an intralingual nature, would do both teachers and learners well to the extent that they could be juxtaposed as a neglected focus on form alongside with such other techniques textual enhancement. A case, therefore, should be made for bringing this technique back into the picture when it comes to the teaching of a grammar of a second language, thereby paving the way for a fruitful journey from the known to the unknown on the part of the learners on one hand, and proving a meaningful learning (Ausubel, 1978) milieu for the teachers on the other. This is in line the view that activating learners' schemas in second language learning ought to be considered of high priority as it has been in other areas of general education (Anderson, 2004; Bundy, 2005; Postrech, 2002; Paik, 2003). The effectiveness of the use of advance organizers has already been attested by a number of research studies (Chung \& Huang, 1998, Hanley et al., 1995, Herron, 1994, and Herron et al., 1998). There is also a large pile of studies suggesting that TE could lead to considerable gains (Jourdenais et al., 1995; Doughty, 2001; Alanen, 1995).

Although advance organizers have not received the attention they have deserved, the results of the current paper could conceivably rekindle the flame of attention toward these useful tools. The use of these tools becomes even more appealing when the target structures are the grammatical properties of the second language. Schema activation has already received a great deal of attention with reading and listening skills to the extent that pre-reading and pre-listening stages have occupied such an important and indelible place in second language curricula and syllabi. However, the importance of schema activation in the teaching of grammar seems to have been more of a lacuna than an actualized learning strategy. It could therefore be suggested that as with listening and reading skills, the scenario of teaching the grammatical and lexical properties of a second language begin with a pre-grammaring phase, and it is at this stage that advance organizers of either interlingual and intralingual nature could be utilized.

There are a number of words on the limitations of the study in order. As the study deals with only intermediate learners, it would be interesting to pose the question whether the same results would be repeated with learners of different levels of language proficiency. Another question concerns the idea of whether a change in the way the target structures were presented or some modifications in the type of the target structures chosen 
The effectiveness of advance organizers versus textual enhancement on learning inchoatives and unaccusatives would have effected changes in the results. These questions and many more call for further research on the area to be conducted in the future.

\section{References:}

Alanen, R. (1995). Input enhancement and rule presentation in SLA. In R. Schmidt (Ed.), Attention and awareness in foreign language learning (pp. 259-302). Honolulu: University of Hawaii Press.

Alipour, J. Youhanaee, M., \& Barati, H. (2014). The comparative effects of advance organizers vs. textual enhancement on the acquisition of English passivization. International Journal of Research Studies in Language Learning. 3(5), 1-12.

Anderson, R. C. (2004). Role of the reader's schema in comprehension, learning, and memory. In R. B. Ruddell, \& N. J. Unrau (Eds.), Theoretical models and processes of reading ( $5^{\text {th }}$ ed.) (pp. 594-606). Newark, DE: International Reading Association.

Ausubel, D. P. (1960). The use of advance organizers in the learning and retention of meaningful verbal material. Journal of Educational Psychology, 51(5), 267-272. http://dx.doi.org/10.1037/h0046669

Ausubel, D. P. (1978). In defense of advance organizers: A reply to the critics. Review of Educational Research, 48, 251-257. http://dx.doi.org/10.3102/00346543048002251

Balcom, P. (1997). Why is this happened? Passive morphology and unaccusativity. Second Language Research. 13(1), 1-9. http://dx.doi.org/10.1191/026765897670080531

Bialystok, E. (1994). Representation and ways of knowing: Three issues in second language acquisition. In N. Ellis (Ed.), Explicit and implicit learning of languages (pp. 549-569). London: Academic Press.

Bundy, J. (2005). An online portfolio by Jason Bundy: California State University, Sacramento for the internet-based masters of educational technology. Retrieved January 3, 2014, from http://imet.csus.edu/imet6/bundy

Bygate, M., Skehan, P., \& Swain, M. (Eds.). (2001). Researching pedagogic tasks: Second language learning, teaching, and testing. New York: Longman.

Chung, J. M., \& Huang, S. C. (1998). The effects of three aural advance organizers for video viewing in a foreign language classroom. System, 26, 553-565. http://dx.doi.org/10.1016/S0346-251X(98)00037-2

DeKeyser, R. (1998). Beyond focus on form: Cognitive perspectives on learning and practicing second language grammar. In C. Doughty \& J. Williams (Eds.), Focus on form in classroom second language acquisition (pp. 42-63). New York: Cambridge University Press.

Denner, P. R., \& Rickards, J. P. (1987). A developmental comparison of the effects of provided and generated questions on text recall. Contemporary Educational Psychology, 12, 135-146. http://dx.doi.org/10.1016/S0361-476X(87)80047-4

Doughty, C. (1991). Second language instruction does make a difference: Evidence from an empirical study of SL relativization. Studies in Second Language Acquisition, 13(4), 431-469. http://dx.doi.org/10.1017/S0272263100010287

Doughty, C. (2001). Cognitive underpinnings of focus on form. In P. Robinson (Ed.), Cognition and second language instruction (pp. 206-257). Cambridge University Press. http://dx.doi.org/10.1017/CBO9781139524780.010

Doughty, C., \& Williams, J. (1998). Pedagogical choices in focus on form. In C. Doughty \& J. Williams (Eds.), Focus on form in classroom second language acquisition (pp. 197-261). New York: Cambridge University Press.

Ellis, R. (1985). Understanding second language acquisition. Oxford University Press.

Ellis, R. (1990). Instructed second language acquisition: Learning in the classroom. Oxford, UK: Blackwell.

Ellis, R. (1994). The study of second language acquisition. Oxford University Press.

Ellis, R. (2002a). Does form-focused instruction affect the acquisition of implicit knowledge? Studies in Second Language Acquisition, 24, 223-236. http://dx.doi.org/10.1017/S0272263102002073

Ellis, R. (2002b). The place of grammar instruction in the second/foreign curriculum. In E. Hinkel \& S. Fotos (Eds.), New perspectives on grammar teaching in second language classrooms (pp. 17-34). Mahwah, 


\section{NJ: Erlbaum.}

Fotos, S. (1993). Consciousness-raising and noticing through focus on form: Grammar task performance versus formal instruction. Applied Linguistics, 14, 385-407. http://dx.doi.org/10.1093/applin/14.4.385

Fotos, S. (1994). Integrating grammar instruction and communicative language use through grammar consciousness-raising tasks. TESOL Quarterly, 28(2), 323-351. http://dx.doi.org/10.2307/3587436

Ginther, A. (2002). Context and content visuals and performance on listening comprehension stimuli. Language Testing, 19(2), 133-167. http://dx.doi.org/10.1191/02655322021t225oa

Glover, J. A. (1989). Improving readers' estimates of learning from text: the role of inserted questions. Reading Research and Instruction, 28(3), 68-75. http://dx.doi.org/10.1080/19388078909557976

Hanley, J., Herron, C., \& Cole, S. P. (1995). Using video as an advance organizer to a written passage in the ELES classroom. The Modern Language Journal, 79(1), 57-66. http://dx.doi.org/10.1111/j.1540-4781.1995.tb05416.x

Harley, B., \& Swain, M. (1984). The interlanguage of immersion students and its implications for second language teaching. In A. Davies, C. Criper, \& A. P. R. Howatt (Eds.), Interlanguage (pp. 291-311). Edinburgh University Press.

Herron, C. (1994). An investigation of the effectiveness of using an advance organizer to introduce video in the foreign language classroom. The Modern Language Journal, 78(2), 190-198. http://dx.doi.org/10.1111/j.1540-4781.1994.tb02032.x

Herron, C., York, H., Cole, S. P., \& Linden, P. (1998). A comparison study of student retention of foreign language video: Declarative versus interrogative advance organizer. The Modern Language Journal, 82(2), 237-247. http://dx.doi.org/10.1111/j.1540-4781.1998.tb01197.x

Izumi, S. (2002). Output, input enhancement, and the noticing hypothesis: An experimental study on ESL relativization. Studies in Second Language Acquisition, 24, 541-577. http://dx.doi.org/10.1017/S0272263102004023

Jourdenais, R., Ota, M., Stauffer, S., Boyson, B., \& Doughty, C. (1995). Does textual enhancement promote noticing? A think-aloud protocol analysis. In R. Schmidt (Ed.), Attention and awareness in foreign language learning (pp. 183-216). Honolulu: University of Hawaii Press.

King, A. (1992). Comparison of self-questioning, summarizing, and note taking-review as strategies for learning from lectures. American Educational Research Journal, 29(2), 303-323. http://dx.doi.org/10.3102/00028312029002303

Kirkman, G., \& Shaw, E.L. (1997). Effects of an oral advanced organizer on immediate and delayed retention. Paper presented at the $26^{\text {th }}$ Annual Meeting of Mid-South Education Research Association (MSERA), Memphis, TN.

Lapkin, S., Hart, D., \& Swain, M. (1991). Early and Middle French immersion programs: French language outcomes. Canadian Modern Language Review, 48, 11-40.

Larsen-Freeman, D. (2003). Teaching language from grammar to grammaring. Boston:Thomson Corporation.

Larsen-Freeman, D., \& Long, M. (1991). An introduction to second language acquisition research. London: Longman.

Lightbown, P. (2000). Anniversary article: Classroom SLA research and second language teaching. Applied Linguistics, 21, 431-462. http://dx.doi.org/10.1093/applin/21.4.431

Long, M. (1983). Does second language instruction make a difference? A review of the research. TESOL Quarterly, 17, 359-382. http://dx.doi.org/10.2307/3586253

Long, M. (1988). Instructed interlanguage development. In L. Beebe (Ed.), Issues in second language acquisition: Multiple perspectives (pp. 115-141). Rowley, MA: Newbury House.

Long, M. (1991). Focus on form: A design feature in language teaching methodology. In K. Debot, R. Ginsberg, \& C. Kramsch (Eds.), Foreign language research in cross-cultural perspective (pp. 39-52). Amsterdam: Benjamins.

Nassaji, H. \& Fotos, S. (2004). Current developments in research on the teaching of grammar. Annual Review of Applied Linguistics, 24, 126-145. http://dx.doi.org/10.1017/S0267190504000066

Osman, M. E., \& Hannafin, M. J. (1994). Effects of advance questioning and prior knowledge on science 
The effectiveness of advance organizers versus textual enhancement on learning inchoatives and unaccusatives

learning. Journal of Educational Research, 88(1), 5-13.

http://dx.doi.org/10.1080/00220671.1994.9944829

Paik, S. J. (2003). Ten strategies that improve learning. Educational Horizons, 81, 83-85.

Perlmutter, D. (1978). Impersonal passives and the unaccusative hypothesis. Proceedings of the 4th Berkeley Linguistics Society, 157-189.

Pienemann, M. (1984). Psychological constraints on the teachability of languages. Studies in Second Language Acquisition, 6, 186-214. http://dx.doi.org/10.1017/S0272263100005015

Pienemann, M. (1988). Determining the influence of instruction on L2 speech processing. AILA Review, 5, 40-72.

Pienemann, M. (1999). Language, processing, and second language development: Processability theory. Amsterdam: Benjamins.

Postrech, R. (2002). Advance organizers. Montclair methods and materials: Discussion forum. Retrieved November 13, 2005, from http://chss2.montclair.edu/sotillos /_meth/00000012.htm

Schmidt, R. W. (1990). The role of consciousness in second language learning. Applied Linguistics, 11(2), 129-158. http://dx.doi.org/10.1093/applin/11.2.129

Schmidt, R. W. (2001). Attention. In P. Robinson (Ed.), Cognition and second language instruction (pp. 3-32). Cambridge University Press. http://dx.doi.org/10.1017/CBO9781139524780.003

Truscott, J. (1998). Noticing in second language acquisition: A critical review. Second Language Research, 14, 103-135. http://dx.doi.org/10.1191/026765898674803209

Vandergrift, L. (2004). Listening to learn or learning to listen? Annual Review of Applied Linguistics, 24, 3-25. http://dx.doi.org/10.1017/S0267190504000017

VanPatten, B.(1996). Input processing and grammar instruction in second language acquisition. Norwood, NJ: Ablex.

White, J. (1998). Getting the learner's attention: A typographical input enhancement study. In C. Doughty \& J. Williams (Eds.), Focus on form in classroom second language acquisition (pp. 85-113). New York: Cambridge University Press.

Yip, V. (1995). Interlanguage and learnability. Amsterdam: John Benjamins Publishing Company. http://dx.doi.org/10.1075/lald.11 
A'lipour, J., Youhanaee, M., \& Barati, H. 